\title{
Cari Açık ve Ekonomik Büyüme Arasındaki Nedensellik İlişkisi: Visegrad Dörtlüsü Örneğii*
}

\section{The Causality Between Current Account Deficit and Economic Growth: The Case of Visegrad Four}

\author{
Yağmur Sağlam, ${ }^{a^{* *}}$ Filiz Erataş Sönmez ${ }^{\mathrm{b}}$
}

${ }^{a}$ Dr. Öğretim Üyesi, Sinop Üniversitesi Boyabat İİBF, İktisat Bölümü, 57200, Sinop/Türkiye. Orcid ID: 0000-0001-6465-0297

${ }^{\text {b }}$ Dr. Öğretim Üyesi, Manisa Celal Bayar Üniversitesi, Salihli İ̈BF, İktisat Bölümü, 45300, Manisa/Türkiye. Orcid ID: 0000-0003-2052-340X

\begin{tabular}{l} 
A R T I C L E I N F O \\
\hline Article history: \\
Received 01 October 2018 \\
Received in revised form 27 October 2018 \\
Accepted 15 November 2018
\end{tabular}

Keywords:

Current Account Deficit

Economic Growth

Panel Data Analysis

MAKALE BILGIISI

Makale Geçmişi:

Başvuru tarihi: 01 Ekim 2018

Düzeltme tarihi: 27 Ekim 2018

Kabul tarihi: 15 Kasım 2018

\section{Anahtar Kelimeler:}

Cari Açık

Ekonomik Büyüme

Panel Veri Analizi

\begin{abstract}
A B S T R ACT
The purpose of this study is to determine the causality between current account deficit and economic growth for Visegrad Four (Poland, Czech Republic, Hungary, Slovakia). In this context, an empirical model was developed in the scope of the panel data analysis using annual data for the period of 1993-2015. Firstly, heterogeneity of the variables was investigated using the Delta test, and then cross section dependency and unit root notions were examined respectively by the CDlm test and Hadri-Kurozumi (2012) test. After the existence of the cointegration relationship between the series was proved by using the Durbin H cointegration test, Dumitrescu-Hurlin panel causality test was applied. According to the empirical results, in the long run there is one-way causality from current account deficit to the economic growth in Visegrad Four.
\end{abstract}

ÖZ

$\mathrm{Bu}$ çalışmanın amacı cari hesap açığı ve ekonomik büyüme değişkenleri arasındaki ilişkiyi Visegrad Dörtlüsü olarak adlandırılan Polonya, Çek Cumhuriyeti, Macaristan ve Slovakya için belirlemektir. Bu bağlamda oluşturulan ampirik model, 1993-2015 yıllarını kapsayan bir dönem için panel veri analizi ile test edilmiştir. Öncelikle değişkenlerin heterojenliği ve yatay kesit bağımlılı̆̆ı sırasıyla Delta ve CDlm testleri ile araştırılmış ve daha sonra Hadri-Kurozumi (2012) birim kök testi yapılmıştır. Değişkenler arasındaki eş-bütünleşme ilişkisinin varlığ Durbin-H testi ile ispat edildikten sonra Dumetrescu-Hurlin (2012) nedensellik testi yapılmıştır. Uygulama bulgularına göre uzun dönemde, seçili Visegrad ülkelerinde cari hesap açığından ekonomik büyümeye doğru tek yönlü bir nedensellik ilişkisi mevcuttur.

\section{Introduction}

Since the 1980s, with the fast pace of the technological progress, liberalization policies of developing countries are significantly raised the level of integration of the real and financial sectors globally. The main contribution of liberalization is that it helps increasing the national savings, investments and finally enables fast growth. However, it is widely known that liberalizing international capital movements without adequate legislations makes countries fragile and more vulnerable against shocks, causing possible financial crises.
Current account deficit is commonly defined as having more expenses than income, in other words, excess investment above savings. This condition simply refers to the situation that the country is indebted to others. Countries with current deficit are expected to have fragile economies and be effected by the shocks easier. One of the reason is that unlegislated countries with weak macroeconomic indicators are not protected against speculative-sudden with no reason capital outflows and rapid reversal of the continuing capital inflow may cause a financial crisis. Because of the risk of capital flight (loss of confidence by investors), foreign ownership of assets (best assets could be bought by them and reduces long-

\footnotetext{
*Bu çalışma, ELSSb IV 2018, Riga konferansında sunulmuştur.

***Sorumlu yazar/Corresponding author

e-posta: yagmur.saglam@ sinop.edu.tr
} 
term income), unbalanced economy, uncompetitive economy, risk of depreciation (imported inflation).

The aim of this study is to analyze the causality relationship between current account deficit and economic growth within Poland, Hungary, Czech Republic and Slovakia using the panel data analysis. First, heterogeneity of the variables was tested by Delta test, then the cross-section dependency in the series was examined. The cointegration within the series was investigated by Durbin $\mathrm{H}$ panel cointegration test. Finally, causality relationship was tested by Dumitrescu and Hurlin Causality Test.

The paper consists of four sections. In the first section the theoretical background of the relationship between current deficit and economic growth is investigated. The second section is about the empirical model. The third part includes econometric methodology and general information about the data set. The last part presents the results of empirical model.

\section{The Relationship Between Current Deficit and Economic Growth}

The current account balance is one of the most important macroeconomic indicators for a country. One reason for its importance is a possible increase of fragility, and due to its effect on market performance expectations, and whether it is sustainability in the long term. It is an important indicator of an economy's health because of its definition. A positive current account balance indicates that your country is a net lender not a borrower or can increase net foreign assets. In addition to this a positive current account means balanced economy but the size of the current account deficit and continuity of this deficit provide negative signs for agents in the market may expect crises.

Another aspect of the relationship between the current deficit and economic growth is fragility of the economy and the possibility of triggering financial crises. Depending on the fragility which is implied by the current deficit, probable negative effect of a financial crisis on economic growth puts a "keep an eye on" mark on the current deficit. The negative effects of current deficit on investments and growth were also stated in the previous literature (see Edwards 2002, and 2004). Moreover, countries which have higher investment rates are less dependent on foreign capital, i.e. they exhibit less current deficit, were claimed to grow faster (Prasad, 2007:161).

There are two main approaches in the literature, which focus on sustainability and causality. Sustainability of a current deficit is naturally critical for financial stability and growth. Although there is not a precise sustainability threshold for a current deficit, the concerns arise when it exceeds $5 \%$ of the Gross Domestic Product (GDP). Additionally, exchange rate policies, saving and investment rates, and financial markets' soundness are considered signs of the economic sustainability (Milesi-Faretti and Razin, 1996:65). Sustainability also has two approaches in the literature. The first one is the national point of view which takes into account consumption and investment, and the second view is the international finance standing which debates on the global investors' portfolios (Kee et al., 2011: 308).

The economic growth is roughly stated as the expansion of production frontier. It is also calculated as an increase in the real per capita output net of price changes after a given year.
As their main goal alongside with development, aspects of the growth varies especially across developing countries. There is a colossal literature in economics about this subject. Some of these studies tried to exert the fundamental ingredients of the growth, others focused on causality relationships amongst other variables such as the current deficit. Lastly, a number of studies examined the convergence within groups of countries.

The literature of the causality relationship between current account deficit and economic growth was summarized and showed in a table below (in which time series and panel data analysis are applied):

Table 1: Literature of Empirical Analysis

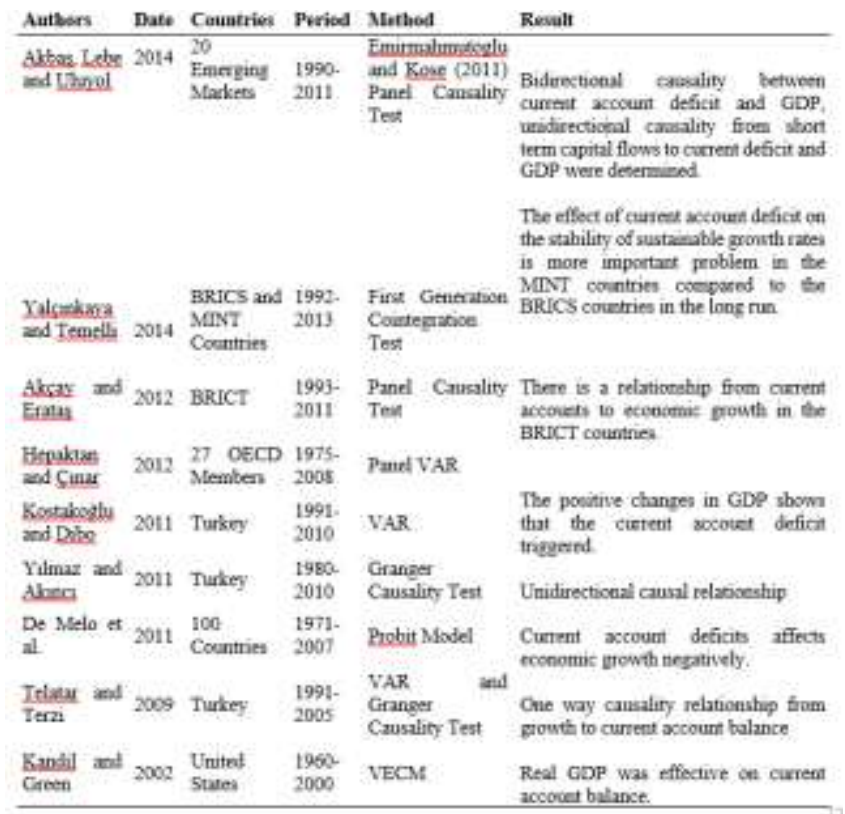

\section{Visegrad Four and Their General Economic Outlook}

After communistic block has collapsed in 1989 the Central European Countries started to sign some agreements between each other. One of them is called Visegrad Four (V4) has been signed by Hungary, Czech Republic Poland and Slovak Republic in $15^{\text {th }}$ of February, 1995. This was a declaration of cooperation with common goals about building democracy, freedom, modern market economy and integration into Europe Brazova et al. (2013: 5).

According to Horvath (2004), the Visegrad community may gain better economic and politic results during the negotiations with European Union because of they cannot behave independently from each other according to their agreement. In the first years they achieved many things as a group such as joining the NATO etc. The force behind of the cooperation was being a part pre-communistic history and being a transition economy. The transition started with Poland in 1991 and the country was very successful even by her own and the ambition of Poland forced it to play a key role according to Pehe (2004) to be a part of Central and Eastern Europe. Their slogan was "back to Europe". Czech Republic and Slovak Republic almost even stopped the V4 
because of their governmental authorities who preferred not integration but isolation.

In May 2004 they became a member of EU after the enlargement of European Union and they promised to complete their political and financial regulations. Especially foreign policy activities have increased after being a part of EU and Schengen Area. Even Austria and Slovenia wanted to be a part of Visegrad Four or regional partnership (Bilcik and Strazay, 2006: 20). In 2011 the leader of these four countries signed also Bratislava Declaration to highlight the importance of V4 one more time.

The Hungarian economy mostly re-shaped by EU regulations in the beginning of $21^{\text {st }}$ century and had rapid economic growth with high degree of openness. Czech Republic refused to be a part of Eurozone till 2019 because of the government needs special policy to manage balance of payments. When you compare Czech Republic with others they have better human development index and technological advantage thanks to structural changes in export and manufacturing industry. From 2003 till 2009 just after joining the EU, Slovakia had the highest unemployment rate but the lowest inflation rate ever due to being part of also Eurozone. After global financial crisis the Polish growth rate decreased sharply along of export independency and it also lowers the current account imbalances. Slovak Republic imported the gas from Russia baut growth rates of energy sector was weak so it shows that EU membership does not affect positively each sector of the countries. In summary all Visegrad countries have current account deficit which means negative current account balance and high level of economic growth (Zhurauliou, 2015: 124-134).

This is why it is important to test the relationship between current account balance and economic growth for the selected countries. This study contributes to the literature in two different way; first there are almost not too many papers written Visegrad countries the written literature and there is a gap to fulfill. The panel data analysis considers heterogeneity and cross-section dependency to not to gain biased results. Especially for regional agreements it is easy to reflect an external or internal shock from one country to another with the dynamics of economy. It is impossible to assume that a demand or supply shock will only affect the country it happened but not the cross-border. Also this study used the most updated data and econometric programs with second generation tests.

\section{Data Set and Methodology}

The aim of this paper is to determine the causality relationship between growth and current account deficit among Visegrad Four. The empirical model is based on the four countries' annual data of growth rate and current account balance from 1993 to 2015 .

The empirical panel data analysis is stated as follows:

\section{C.A: Current Account Balance (\% of GDP)}

G: GDP Growth (annual \%)

The data set is obtained from World Bank Development Indicators with their natural logarithmic forms which is $\%$ of GDP.

\subsection{Empirical Results and Evaluation}

\subsubsection{Heterogeneity}

As a starting point, homogeneity of the variables have been examined via delta test. Homogeneity of the variables has an effect on the directions and structures of following unit root and cointegration tests.

Table 2: Delta Test Results

\begin{tabular}{lll}
\hline Test & T-Statistics & Prob. \\
\hline$\tilde{\Delta}$ & -0.020 & 0.508 \\
$\tilde{\Delta}_{\text {adj }}$ & -0.021 & 0.508
\end{tabular}

According to the results on Table 2, the variables in the panel data model are homogeneous. Because probability is not significant and $H_{0}$ null hypothesis is not rejected.

\subsubsection{Cross-sectional Dependency}

It is important to find out the cross sectional independencies for the series which are proven to be heterogeneous with the delta test. The independence of the cross sectional data can also be stated as to whether all the cross sectional data be affected equally by a shock at any time or not.

The CDlmtest statistic is to be obtained by the equation above in order to examine the cross-sectional independence. A contemporaneous correlation, low or high, is expected between the residuals.

Table 3: Cross-section Dependence Test (C.A.)

\begin{tabular}{|c|c|c|}
\hline CD Test & T-Statistics & Prob \\
\hline LM $_{(\text {Breusch, Pagan 1980) }}$ & 32.721 & 0.000 \\
\hline CD LM 1 (Pesaran 2004) & 7.714 & 0.000 \\
\hline CD LM 2 (Pesaran2004) & -1.765 & 0.039 \\
\hline $\begin{array}{l}\text { Bias-adjusted CD (Pesaran } \\
\text { et al. 2008) }\end{array}$ & 2.800 & 0.003 \\
\hline
\end{tabular}

According to the results presented in Table 3, the null hypothesis, cross sectional independence of variable C.A., is rejected. So there is a dependency between the cross sections. 
Table 4: Cross-section Dependency Test $(G)$

\begin{tabular}{lll}
\hline CD Test & T-Statistics & Prob \\
\hline LM $_{\text {(Breusch, Pagan 1980) }}$ & 23.072 & 0.001 \\
CD LM 1 (Pesaran 2004) & 4.928 & 0.000 \\
CD LM 2 (Pesaran2004) & -2.159 & 0.015 \\
$\begin{array}{l}\text { Bias-adjusted CD (Pesaran } \\
\text { et al. 2008) }\end{array}$ & 5.013 & 0.000 \\
\hline
\end{tabular}

The null hypothesis is rejected, because the probability is less than 0.05 for all calculated test statistics. So it's possible to say that there is a dependency between the cross sections composing $\mathrm{G}$.

\subsubsection{Stationary}

Unit root tests which take into account the cross section dependency are called the second generation unit root tests. One of them is the test which is developed by Hadri and Kurozumi (HK) in 2012. This test is better than Coaugmented Dicky Fuller (CADF) unit root test under the circumstances that you cannot reject null hypothesis of CADF because the hypothesis of HK (2012) claims that there is unit root. The test calculates to different test statistics which are ZA_la and ZA_spc. It assumes that they have normal distribution.

Table 5:HK Unit Root Test Results for All Variables

\begin{tabular}{|c|c|c|c|c|}
\hline \multirow{2}{*}{ Level } & \multicolumn{2}{|c|}{ Constant } & \multicolumn{2}{|c|}{ Constant and Trend } \\
\hline & T-stat. & Prob. & T-stat. & Prob. \\
\hline \multicolumn{5}{|l|}{ C.A. } \\
\hline ZA_spc & 3.3610 & 0.0004 & 2.0140 & 0.0220 \\
\hline ZA_la & 1.5746 & 0.0577 & 4.7237 & 0.0000 \\
\hline \multicolumn{5}{|l|}{$G$} \\
\hline ZA_spc & 0.9188 & 0.1791 & 1.0536 & 0.1460 \\
\hline ZA_la & 0.8510 & 0.1974 & 0.6840 & 0.2470 \\
\hline \multicolumn{5}{|c|}{$\begin{array}{l}\text { First } \\
\text { Diffrence }\end{array}$} \\
\hline \multicolumn{5}{|l|}{ C.A. } \\
\hline ZA_spc & 0.9658 & 0.1671 & 68.4742 & 0.0000 \\
\hline ZA_la & 1.5294 & 0.0631 & 70.3359 & 0.0000 \\
\hline \multicolumn{5}{|l|}{$G$} \\
\hline ZA_spc & 3.3881 & 0.0004 & 8.8596 & 0.0000 \\
\hline ZA_la & 2.7459 & 0.0030 & 8.2895 & 0.0000 \\
\hline
\end{tabular}

The maximum lag length is 4 and chosen according to Schwarz criteria.
ZA_spc has developed by Sul et al. (2005) and represent long term variance test statistic of augmented KPSS test. ZA_la has developed by Choi (1993); Toda and Yamamato (1995) and represents augmented KPSS test statistic for panel data. According to table 5 the variables have unit root on their level but after first differences they are stationary. Because of their probability value is under 0.005 .

\subsubsection{Panel Cointegration}

The results, which are obtained from panel unit root tests, are crucial for the panel cointegration tests. While setting up the assumptions for the panel cointegration tests, considering stationarity orders of the variables can change the type of the test. Series taken into consideration exhibit cross sectional dependency, which suggests using second generation panel cointegration tests that takes it into consideration.

Table 6: Durbin-H Test Results

\begin{tabular}{lll}
\hline & Test Statistics & Bootstrap Prob. \\
\hline $\boldsymbol{D} \boldsymbol{H}_{p}$ & 83.938 & 0.000 \\
$D \boldsymbol{H}_{g}$ & 153.084 & 0.000
\end{tabular}

According to the results, null hypothesis is rejected. Bootstrap values was taken into account because of the crosssectional dependency when the numerical values were being interpreted. The results prove the cointegration among all the cross sections within the panel.

4.1.5. Panel Causality

Dumitrescu and Hurlin (2012) test can be used to estimate for both dependent and independent cross sections (Dumitrescu and Hurlin, 2012:1). This test has similarities to Granger causality test. The test refers to the mean of Wald tests calculated for Granger causality test (Dumitrescu and Hurlin, 2012:1). Dumitrescu and Hurlin test works for both of the cases where there is cointegration or not.

Table 7: Dumitrescu and Hurlin Causality Test Results

\begin{tabular}{|c|c|c|c|}
\hline $\begin{array}{l}\text { Null } \\
\text { Hypothesis }\end{array}$ & Test & Statistic & Prob. \\
\hline \multirow{4}{*}{$\begin{array}{l}\text { C.A does not } \\
\text { Granger cause } \mathbf{G}\end{array}$} & & & \\
\hline & Whnc & 1.796700 & $0.079420 *$ \\
\hline & Zhnc & 1.126704 & 0.211470 \\
\hline & Ztild & 0.784375 & 0.293300 \\
\hline \multirow{4}{*}{$\begin{array}{l}\text { G does not } \\
\text { Granger cause } \\
\text { C.A }\end{array}$} & & & \\
\hline & Whnc & 1.434129 & 0.142659 \\
\hline & Zhnc & 0.613951 & 0.330415 \\
\hline & Ztild & 0.365568 & 0.373156 \\
\hline
\end{tabular}

*represents $10 \%$ statistical significance. 
When the results in Table 7 are examined, it is clearly seen that there is one-way causality from current account deficit to growth rate. Because only 0.079420 is under 0.10 and statistically significant.

\section{Conclusion}

Nowadays, the current account deficit is very important for many countries as a product of the financial globalization. From the late 90s to the latest global financial crisis, many countries exhibit increasing current account deficits. These deficits increase the fragility of the national economies and at the same time they contribute to the economic growth. In case of emerging market countries, the current account deficits have been financed by speculative and debtincreasing resources.

The current account deficit allows a country to consume more than it produces or invest more than it saves. Economic growth can be achieved or increased through foreign capital transfers. The concept of the current deficit can be harmless and useful especially when the financing of the deficit is sustainable.

The results of this study exhibit the cointegration between current deficit and growth. In other words, current account deficit and economic growth tend to move together in the long run. Under this assumption, causality test has been conducted and it shows that there is a unidirectional causality relationship between the economic growth and the current account deficit. In this context, it becomes important for regional agreements and Visegrad Four to find out the reason why only current account balance affects the economic growth but not vice-versa. Possible solutions for current account deficit in Visegrad Four; to raise national savings (with the help of communistic times saving habits especially for elderly people that the population over 65 is really high in Visegrad Four) and shrink the external deficit, complementary policy changes such as; new industry structure (production of tradable goods) and tax service, moving to Eurozone before than it has planned for Hungary and Czech Republic to control monetary policy.

\section{References}

Akbaş, Y. E., Lebe, F. \& Uluyol, O. (2014). Analyzing the relationship among the GDP - Current account deficit and short term capital flows: The case of emerging markets, Journal of Management and Economics, 21(2), 293-303.

Akçay, A. \& Erataş, F. (2012). Cari açık ve ekonomik büyüme ilişkisinin panel nedensellik analizi ekseninde değerlendirilmesi,http://teacongress.org/papers2012/AKC AY-ERATAS.pdf, 08.04.2016.

Arellano, M. (2003). Panel data econometrics advanced texts in econometrics, Great Britain: Oxford University Press.

Baltagi, B. H., (2013). Econometric analysis of panel data, England: John Wiley \& Sons Ltd.
Bilcik, V. \& Strazay, T. (2006). Functioning of Visegrad four before and after the entry of its members into the EU, Research center SFPA. [cit.1.2.2011]. http://www.sfpa.sk/sk/, 11.02.2017.

Breusch, T. \& Pagan, A. (1980), "The Lagrange Multiplier Test and its Application to Model Specifications in Econometrics", Reviews of Economics Studies, 47, 239253.

Brazova, V.K., Matczak, P. \& Takacs, V. (2013). Regional organization study: Visegrad group, Analysis of Civil Security Systems in Europe, Adam Mickiewicz University.

Choi, I. (1993). Improving empirical size of the KPSS Test of stationary. Online Access http://hompi.sogang.ac.kr/inchoi/workingpaper/in_choijetem-_revision_2.pdf, 11.02.2017.

De Mello, L., Padoan, P. C. \& Rousová, L. (2011). The growth effect of current-account reversals, http://www.voxeu.org/article/growth-effect-currentaccount-reversals, 08.04.2016.

Dumetriscu, E.I. \& Hurlin, C. (2012). Testing for Granger non-causality in heterogeneous panels,Economic Modelling, 29(4), 1450-1460.

Edwards, S. (2002). Does the current account matter?, Preventing Currency Crises in Emerging Markets, Sebastian Edwards and Jeffrey A. Frankel, (editors), The University of Chicago Press.

Edwards, S. (2004). Financial ppenness: Sudden stops and current account reversals", NBER Working Paper, No: 10277.

Güloğlu, B. \& İspir, S. (2009). Yeni gelişmeler 1şı̆̆ında Türkiye'de satın alma gücü paritesi önsavının panel birim kök sınaması, Pamukkale University CASE-Economics Department Publishings.

Güloğlu, B. \& İvrendi, M., (2010). Output fluctuations: Transitory or permanent? The case of Latin America, Applied Economics Letters, 17, 381-386.

Hadri, K. \& Kurozumi, E. (2012). A simple panel stationarity test in the presence of serial correlation and a common factor, Economics Letter, 115, 31-34.

Hepaktan, E. \& Çınar, S. (2012). OECD ülkelerinde büyümecari işlemler dengesi ilişkisi: Panel veri analizi, Anadolu Universitesi Sosyal Bilimler Dergisi, 12(1), 43-58.

Horvath, P. (2004). Central Europe and its integration efforts, In Slovenská politologická revue, číslo 2.

Kandil, M. \& Greene, J. (2002). The impact of cyclical factors on the U.S. balance of payments, IMF Working Paper, No.45.

Kee, C. H., Wong. S. C. \& Siok, K. S. (2011). An empirical study on the convergence of current account in emerging East-Asian countries, 2011 International Conference on Sociality and Economics Development, IPEDR, 10, 308312.

Kostakoğlu, S. F. \& Dibo, M. (2011). Türkiye'de cari açık ve ekonomik büyüme ilişkisinin VAR yöntemi ile analizi, 
Anadolu International Conference in Economics II, June 15-17, Eskişehir, Turkey.

Milesi-Ferretti, M. G. \& Razin, A. (1996). Current account sustainability, Princeton Studies in International Finance, 81, 1-78.

Nazlıŏlu, Ş. (2010). Makro iktisat politikalarının tarım sektörü üzerindeki etkisi: Gelişmiş ve gelişmekte olan ülkeler için bir karşılaştırma, Unpublished Doctorate Dissertation, Erciyes University, Institute of Social Sciences.

Pehe, J. (2004). Will the Visegrad cooperation terminate?, Visegrad Info. www.visegradinfo.com, 11.02.2017.

Pesaran, H. M., (2004). General diagnostic tests for cross section dependence in panels, Working Paper, No:0435, University of Cambridge.

Pesaran, H. M., (2007). A simple panel unit root test in the presence of cross section dependence, Journal of Applied Econometrics, 22(2), 265-312.

Pesaran, H. M. \& Yamagata, T. (2008). Testing slope homogeneity in large panels, Journal of Econometrics, 142, 50-93.

Pesaran, H. M., Ullah, A. \& Yamagata, T. (2008). A biasadjusted LM test of error crosssection independence, The Econometrics Journal, 11(1), 105-127.

Prasad, E. S., Raghuram G. R. \& Subramanian, A. (2007). Foreign capital and economic growth, Brookings Papers on Economic Activity, (1), 153-209.

Sul, D., Phillips, P. C. B. \& Choi, C. Y. (2005). Prewhitening bias in HAC estimation, Oxford Bulletin of Economics and Statistics, 67, 517-546.

Telatar, O. M. \& Terzi, H. (2009). Türkiye'de ekonomik büyüme ve cari işlemler dengesi ilişkisi, Atatürk Üniversitesi College of Administrative Sciences and Economics Journal, 23(2), 119-134.

Westerlund, J. (2008). Panel cointegration tests of the Fisher effect, Journal of Applied Econometrics, 23, 193-233.

Yalçınkaya, Ö. \& Temelli, F. (2014). Ekonomik büyüme ile cari işlemler dengesi arasındaki ilişki: BRICS ve MINT (1992-2013), Süleyman Demirel Üniversitesi İktisadi ve İdari Bilimler Fakültesi Dergisi, 4(19), 201-224.

Yılmaz, Ö. \& Akıncı, M. (2011). İktisadi büyüme ile cari işlemler bilançosu arasındaki ilişki: Türkiye örneği,Atatürk Üniversitesi Institute of Social Sciences Journal, 15(2), 363-377. 